\title{
Using Social Media to Change Smoking Behavior: Line Instant Messaging Application Perspectives
}

\author{
Ratchanee Kulsolkookiet \\ Thailand Tobacco Monopoly \\ Nitaya Wongpinunwatana \\ Thammasat University \\ Lovepon Savaraj \\ Kasetsart University \\ Thunyanee Pothisarn \\ Chiang Mai University
}

The objective of this study is to examine the influence of anti-smoking multimedia on smoking-cessation behavior with respect to attitude towards smoking, belief in subjective norms of smoking, perceived behavioral control of smoking, intentions to reduce smoking, and motivation for smoking cessation. The study is based on an experimental research. The experimental design consisted of three types of multimedia anti-smoking campaigns (text, text with pictures, and video), and three levels of human caring (environment, surrounding people, and themselves). A total of 90 graduate and undergraduate students participated in the experiment. The findings suggested that participants (1) have unfavorable attitudes towards smoking, (2) are indifferent to belief in subjective norms of smoking, and (3) possess greater perceived behavioral control of smoking after viewing the anti-smoking multimedia campaign for the three levels of human caring. Furthermore, the research found that perceived behavioral control of smoking indirectly influences smoking cessation behavior via intention to reduce smoking. Finally, motivation for smoking cessation directly affects smoking cessation behavior.

\section{INTRODUCTION}

A survey conducted by the National Statistical Office in 2014 indicated that around $21 \%$ of the population of Thailand over the age of 15 years (or about 11.4 million people) are cigarette smokers. Consequently, because of the high number of smokers, smoking-related illnesses are a significant problem. Though Thai Health Promotion Foundation produced anti-smoking campaigns in two categories - harm related to cigarettes, and need for stringent legal enforcement related to cigarettes - the campaigns have apparently been unsuccessful since the revenue from cigarette sales between 2009 and 2011 increased during the anti-smoking campaigns (see Table 1). Thai Health Promotion Foundation also found that the anti-smoking campaigns may not have reached two target groups - new youth smokers and 
young females. Moreover, the survey conducted by the National Statistical Office showed an increase in younger smokers with ages 15 to 24 years.

TABLE 1

COMPARISON OF REVENUE FROM SALES OF CIGARETTES (IN USD MILLIONS) AND TIMING OF ANTI-SMOKING CAMPAIGNS

\begin{tabular}{|l|l|l|c|c|c|c|}
\hline \multicolumn{1}{|c|}{ Item } & \multicolumn{1}{|c|}{$\mathbf{2 0 0 9}$} & \multicolumn{1}{c|}{$\mathbf{2 0 1 0}$} & $\mathbf{2 0 1 1}$ & $\mathbf{2 0 1 2}$ & $\mathbf{2 0 1 3}$ & \multicolumn{1}{|c|}{$\mathbf{2 0 1 4}$} \\
\hline $\begin{array}{l}\text { Revenue from } \\
\text { sales of } \\
\text { cigarettes }\end{array}$ & $\$ 1,662.1$ & $\$ 1,954.9$ & $\$ 2,070.2$ & $\$ 2,089.7$ & $\$ 2,316.3$ & $\$ 2,042.4$ \\
\hline $\begin{array}{l}\text { Anti-smoking } \\
\text { campaigns from } \\
\text { Thai Health } \\
\begin{array}{l}\text { Promotion } \\
\text { Foundation }\end{array}\end{array}$ & $\begin{array}{l}\text { Increase in } \\
\text { tax for } \\
\text { cigarettes, } \\
80-85 \%\end{array}$ & $\begin{array}{l}\text { Anti- } \\
\text { smoking } \\
\text { campaign in } \\
\text { the form of } \\
\text { text and } \\
\text { pictures on } \\
\text { cigarette } \\
\text { packages, } \\
\text { and defined } \\
\text { no-smoking } \\
\text { areas }\end{array}$ & $\begin{array}{c}\text { no } \\
\text { campaign }\end{array}$ & $\begin{array}{c}\text { no } \\
\text { campaign }\end{array}$ & $\begin{array}{c}\text { no } \\
\text { campaign }\end{array}$ & $\begin{array}{l}\text { Enlarged } \\
\text { size of text } \\
\text { and pictures } \\
\text { on cigarette } \\
\text { packages }\end{array}$ \\
\hline
\end{tabular}

Source: National Statistical Office (2014) and Thai Health Promotion Foundation (2014)

The above data indicates that the anti-smoking campaigns of Thai Health Promotion Foundation may not be as successful as hoped. Possible reasons could be that the anti-smoking channels and methods did not widely reach the target groups, or that the content of the anti-smoking campaigns was not clear.

The main objective of this research is to study the effects of information presentation of anti-smoking campaigns on the attitude towards smoking, belief in the subjective norms of smoking, and perceived behavioral control of smoking. In addition, a study was made to examine whether or not the theory of planned behavior, cognitive theory of multimedia learning, and communication theory are able to predict smoking behavior. Moreover, the preferred channel for the anti-smoking campaigns in this research is Line instant messaging application. Line is a freeware social media application for instant communication on electronic devices such as smartphones, tablets and personal computers. This application is widely used in several countries in Asia.

\section{THEORETICAL BACKGROUND}

This study focuses on multimedia presentations such as text, text and pictures, and video, and whether this multimedia affects the intention to change smoking behavior with respect to three social psychological theories: theory of planned behavior, cognitive theory of multimedia learning, and communication theory.

\section{Theory of planned behavior}

The theory of planned behavior was developed from the theory of reasoned action by Ajzen and Fishbein (2005). This theory posits that human behavior is directly affected by the intention to behave, and indirectly affected by the attitude towards the behavior, belief in subjective norms, and perceived behavioral control via intention to behave.

Attitude towards the behavior is the feeling of persons assessing whether such behavior is good or not good (Ajzen and Fishbein, 2005; Kraft et al., 2005; Cameron et al., 2012). Several research studies show 
that the attitude towards the behavior will have an impact on understanding and cause the behavior to change (Bizer et al., 2003; Schiffiman et al., 2006).

Belief in subjective norms means the individual's perception that other persons have influence on the individual's behavior. When the individual is aware of another person's (or other persons') need to influence, or even oppose the individual's behavior, the individual has a tendency to revise or not to revise such behavior (Ajzen and Fishbein, 2005; Kraft et al., 2005). A study on purchasing decisions determined that family members, friends and surrounding persons influence a person's behavior (Bicchieri and Muldoon, 2011; Pande and Soodan, 2015). Likewise, the study of Al-Swidi et al. (2013) found that the social normative group has a significant impact on the intention to make a purchase.

Perceived behavioral control means the perception of persons on their ability to act or control their goals in accordance with their desires (Ajzen and Fishbein, 2005; Kotler and Keller, 2012; Cameron et al., 2012). A study on factors influencing personal perception found that perceived behavioral control is the basic factor determining intended behavior (Egmond and Bruel, 2007).

Intention to behave means concentrating on what to choose to do. Intention to behave is influenced by the attitude towards the behavior, subjective norms, and perceived behavior control. In addition, the intention to behave affects behavior (Ajzen and Fishbein, 2005; Pande and Soodan, 2015).

Behavior means any act made by a person encountering a stimulus. Behavior is classified as external or internal. External behavior is behavior that can be seen or observed such as walking, laughing, and talking. Internal behavior is behavior that cannot be seen or observed directly until the person speaks about it or has done something to obtain attention of others. Examples of internal behavior are thought, emotion and perception (Ajzen and Fishbein, 2005; Schiffiman et al., 2006).

Four factors affecting behavior are as follows (Levitt, 2013): First, cultural factor is the basic factor determining the need and behavior of people. This factor determines the difference between one society and another society. Second, social factor encompasses the daily life influences of group and family on behavior. Third, personal factor includes the attributes of a person such as age, family life cycle, economic situation, daily life planning, personality and concepts related to the individual. Fourth, psychological factor consists of motivation, perception, learning, belief and attitude, and in addition, the motivation's effects on a person's performance (Mo, 2011).

\section{Cognitive Theory of Multimedia Learning}

The cognitive theory of multimedia learning states that multimedia promotes efficient learning (Mayer, 2005). People can learn the messages of the content within multimedia by listening, watching, or reacting with multimedia (Maoyan et al., 2014). In addition, Plass et al. (2009) stated that content incorporated in multimedia helps people clearly understand those messages. Other researchers such as Morvan et al. (2009) and Harsono and Suryana (2014) indicated that a presentation with text, text with pictures or video can be used to present a product in the media to motivate consumers. Multimedia can be text, pictures, animation, sound and video. Each type of multimedia has different characteristics as follows:

(1) Text together with color is the basic form of multimedia. This form of multimedia can be used to determine the nature of the response during a presentation.

(2) Pictures include photographs and drawings. Pictures play a key role in multimedia - more than text - because the recipient can view the image and the meaning is better transmitted than text. Text is restricted by differences in language, while pictures are more effective in communicating with people of different cultures. This is why images are seen on many types of media, such as television programs, newspapers and websites.

(3) Animation is a graphic illustration that makes movement to present steps or events continuously to create imagination and motivation among viewers.

(4) Sound is a key component of multimedia contained in the digital form that can be played repeatedly. If a captivating sound is used in conjunction with a presentation, such multimedia will be more complete and more interesting in attracting the attention of viewers. 
(5) Video is another key multimedia type in the digital system that presents text, images or video with sound in a complete form, and is often superior to other multimedia components (Mcgloughlin, 2001).

\section{Communication Theory}

Communication is the principle of transmitting and delivering information. Basic elements of communication consist of sender, channel, receiver, and message. Nowadays, the communication channel may be Line, Facebook, YouTube, or similar media. The communication theory posits that effective communication is dependent on the quality of the elements of communication. Many people now consider social media such as Facebook, Twitter, LinkedIn and YouTube to be the best channels that businesses can use to communicate with their consumers. Additionally, instant messaging applications such as Line and WhatsApp are another form of social media that can be used to provide information, which in turn can change receivers' behavior (Smith and Vardiabasis, 2010).

\section{RESEARCH MODEL AND HYPOTHESES}

Following the theory of planned behavior, cognitive theory of multimedia learning, and communication theory, this research posits that the multimedia presentation pattern will affect the attitude towards smoking, belief in subjective norms of smoking, and perceived behavioral control of smoking, while these three factors also affect the intention to reduce smoking. In addition, the intention to reduce smoking directly affects smoking cessation behavior. Apart from multimedia presentation, this study also adds the motivation factor to the theory of planned behavior to predict smoking cessation behavior. The model of the effect of multimedia on smoking cessation behavior is shown in Figure 1.

FIGURE 1

\section{MODEL OF THE EFFECT OF MULTIMEDIA ON SMOKING CESSATION BEHAVIOR}

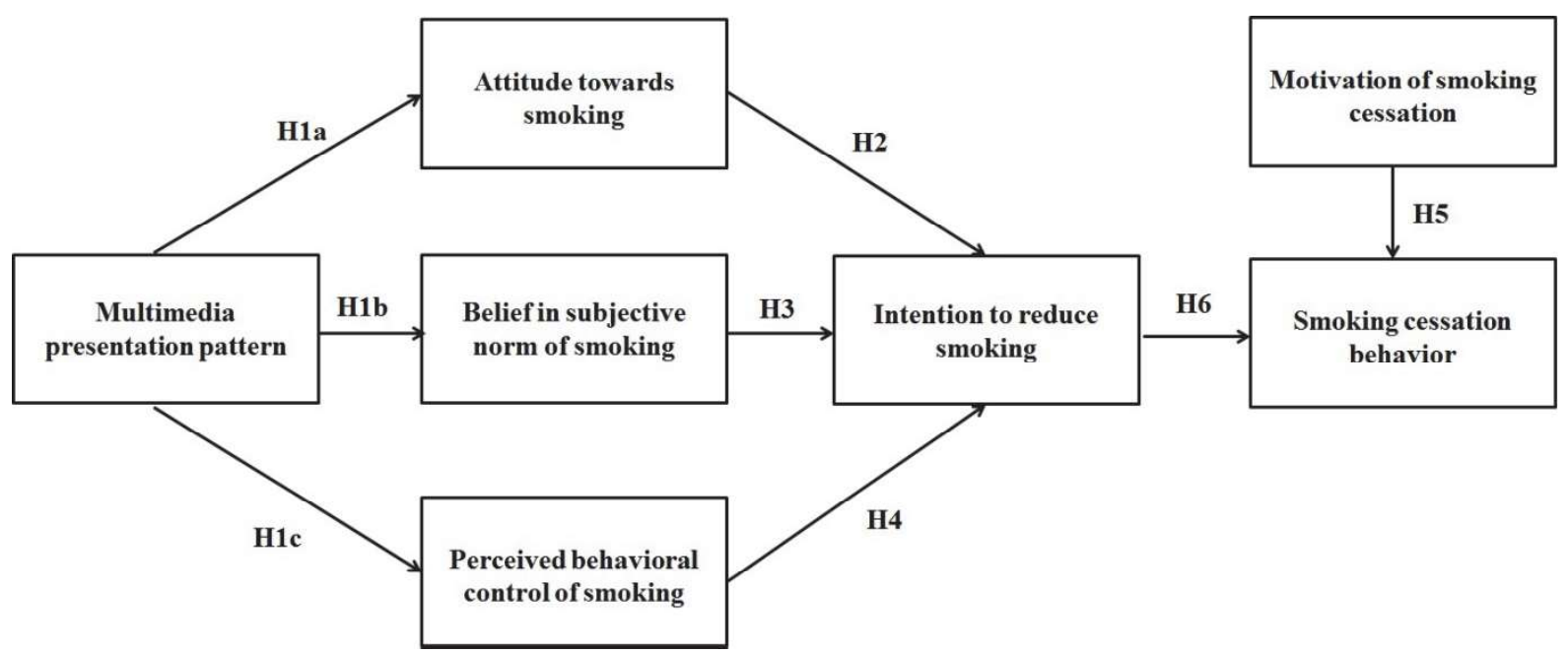

Generally, multimedia is employed to stimulate receivers to learn and absorb the messages. The message may be sent through multimedia in different forms such as text, text with pictures, and video. Different cartoon images to stimulate emotions and to show the dangers of cigarettes could cause a negative feeling among smokers and may induce positive expectation (Harsono and Suryana, 2014; Mahagunta and Anglin, 2007). In addition, people who are aware of the dangers of cigarettes from various multimedia could distinguish themselves from the group without any opposing reaction. Hence, this study proposes that: 
H1a: When presented with different types of anti-smoking multimedia campaigns, the participants' mean score of attitude towards smoking are lower at the post-test stage than at the pre-test stage.

H1b: When presented with different types of anti-smoking multimedia campaigns, the participants' mean score of belief in subjective norms of smoking are lower at the post-test stage than at the pre-test stage.

H1c: When presented with different types of anti-smoking multimedia campaigns, the participants' mean score of perceived behavioral control of smoking are higher at the post-test stage than at the pre-test stage.

Jain (2014) found that attitude towards smoking affects smoking behavior. In addition, perceived behavioral control of smoking directly affects the intention to smoke. Finally, the referenced group and the family have influence on personal behavior (Kotler and Keller, 2012; Mohan, 2014). Hence, this study proposes that:

H2: Attitude towards smoking negatively affects intention to reduce smoking.

H3: Belief in subjective norms of smoking positively affects intention to reduce smoking.

H4: Perceived behavioral control of smoking positively affects intention to reduce smoking.

A psychologist stated that motivation made regularly is required to ensure achievement (Gerber and Rogers, 2009). Therefore, motivation may influence behavior. Hence, this study proposes that:

H5: Motivation of smoking cessation positively affects smoking cessation behavior.

Prior research on behavior posits that intention to behave affects behavior (Kraft et al., 2005; Schiffiman et al., 2006; Cameron et al., 2012). Thus, this study hypothesizes that:

H6: Intention to reduce smoking positively affects smoking cessation behavior.

\section{METHOD}

\section{Research Design}

A laboratory experiment was designed to gather data to test $\mathrm{H} 1 \mathrm{a}-\mathrm{H} 1 \mathrm{c}$ while a survey was used to test H2 - H6. Figure 2 shows the experimental design. It consists of anti-smoking campaigns in three types of multimedia, and three levels of human caring. The three types of anti-smoking multimedia campaigns are text, text with pictures, and video. The three levels of human caring are in accordance with Watson's Human Caring Theory (Watson, 2008). Watson states that people care for the environment, surrounding people, and themselves. Participants were divided into three groups with thirty people in each group. Groups 1, 2, and 3 received three anti-smoking multimedia campaigns for each human caring type.

\section{FIGURE 2 \\ RESEARCH DESIGN}

\begin{tabular}{|l|c|c|c|}
\hline \multirow{2}{*}{$\begin{array}{l}\text { Anti-smoking } \\
\text { multimedia } \\
\text { campaign }\end{array}$} & Environment & Surrounding people & Themselves \\
\cline { 1 - 2 } Text & \multirow{2}{*}{30 samples } & 30 samples & 30 samples \\
\hline Text with pictures & & & \\
\hline Video & & 3 saman caring level \\
\hline
\end{tabular}




\section{Construction of the Research Instruments}

Six different anti-smoking multimedia campaigns (as shown in Table 2) and surveys were prepared for data collection. The contents of anti-smoking multimedia campaigns in the form of text are "Environment disrupted by smoking cigarettes", "Pregnancy disrupted by smoking cigarettes", and "Laryngeal cancer caused by smoking cigarettes" for caring of the environment, surrounding people, and themselves respectively. The contents of anti-smoking multimedia campaigns in the form of text with pictures are the combination of text with related pictures. The contents of anti-smoking multimedia campaigns in the form of video are movies related to contents of anti-smoking campaigns in the form of text.

TABLE 2

SIX DIFFERENT ANTI-SMOKING MULTIMEDIA CAMPAIGNS

\begin{tabular}{|c|c|c|c|}
\hline \multirow{2}{*}{$\begin{array}{l}\text { Anti-smoking } \\
\text { multimedia } \\
\text { campaign }\end{array}$} & \multicolumn{3}{|c|}{ Human caring level } \\
\hline & Environment & Surrounding people & Themselves \\
\hline Text & $\begin{array}{c}\text { สูบบุหรี่ } \\
\text { ทำให้เสียบรรยากาศ }\end{array}$ & $\begin{array}{c}\text { ควันบุหรี่ } \\
\text { มีผลต่อลูกในครรภ์ }\end{array}$ & $\begin{array}{l}\text { ภัยมืดจากบุหรี่... } \\
\text { มะเร็งกล่องเสียง }\end{array}$ \\
\hline Text with pictures & สูบบุหรี่ทำให้เสียบรรยากาศ & $\begin{array}{l}\text { ควันบุหรี่ } \\
\text { มีผลต่อ ๑กำu } \\
\text { ลูกในครรภ์ }\end{array}$ & $\begin{array}{c}\text { ภัยมีดจากบุหรี่... } \\
\text { มะเร็งกล่องเสียง }\end{array}$ \\
\hline Video & & & \\
\hline
\end{tabular}

Items in the survey for factors affecting smoking cessation behavior in the research model (Figure 1) are adapted from Ajzen (1991) and Ajzen and Fishbein (2005). The survey is divided into two sections. Section one contains (1) three pre-test and post-test subsections to measure participants' attitude toward smoking, belief in subjective norms of smoking, and perceived behavioral control of smoking, (2) three post-test subsections to measure participants' intention to reduce smoking, motivation, and smoking cessation behavior (as shown in Table 3). A six-point scale from 1 for 'strongly agree' to 6 for 'strongly disagree' are used for these questions. Section two is used to obtain participants' demographic data, behavior in smoking cigarettes and ranking of communication channels and types of anti-smoking multimedia. 


\section{TABLE 3}

\section{QUESTIONS FOR MODEL OF THE EFFECT OF MULTIMEDIA ON SMOKING CESSATION}

BEHAVIOR

\begin{tabular}{|c|c|}
\hline Factors & Items \\
\hline $\begin{array}{l}\text { Attitude towards } \\
\text { smoking }\end{array}$ & $\begin{array}{l}\text { 1. Smoking makes me feel good. } \\
\text { 2. Smoking has no health effects. } \\
\text { 3. Smoking relieves stress. } \\
\text { 4. Smoking increases attraction from other people }\end{array}$ \\
\hline $\begin{array}{l}\text { Belief in subjective } \\
\text { norms of smoking }\end{array}$ & $\begin{array}{l}\text { 1. My close friend convinced me to smoke. } \\
\text { 2. Smoking gains me acceptance from my friends. } \\
\text { 3. My friends look happy when they smoke so I want to try. }\end{array}$ \\
\hline $\begin{array}{l}\text { Perceived behavioral } \\
\text { control of smoking }\end{array}$ & $\begin{array}{l}\text { 1. I can easily control my smoking behavior. } \\
\text { 2. My smoking behavior can be controlled when I think about smoking } \\
\text { dangers. } \\
\text { 3. I am able to explore ways to control my smoking behavior. }\end{array}$ \\
\hline $\begin{array}{l}\text { Intention to reduce } \\
\text { smoking }\end{array}$ & $\begin{array}{l}\text { I think I will try to cut down my smoking. } \\
\text { 2. I recommend other smokers to cut down smoking. } \\
\text { 3. I plan to cut down smoking. }\end{array}$ \\
\hline $\begin{array}{l}\text { Motivation for } \\
\text { smoking cessation }\end{array}$ & $\begin{array}{l}\text { 1. I will be rewarded if I quit smoking. } \\
\text { 2. I choose to quit smoking because I will be proud of myself. } \\
\text { 3. I quit smoking to gain public acceptance. } \\
\text { 4. The most critical point for me is to gain acceptance from smoking } \\
\text { cessation. }\end{array}$ \\
\hline $\begin{array}{l}\text { Smoking cessation } \\
\text { behavior }\end{array}$ & $\begin{array}{l}\text { 1. I smoke once a week at least one cigarette. } \\
\text { 2. I smoke 3-4 times a week at least one cigarette. } \\
\text { 3. I smoke one cigarette every day. } \\
\text { 4. I smoke more than one cigarette per day. }\end{array}$ \\
\hline
\end{tabular}

Three sets of anti-smoking campaign videos (environment, surrounding people, and themselves) were submitted to an advertising agency for comments. The videos' lengths are 29, 31, and 32 seconds respectively. The comments from the advertising agency were that the contents and lengths of the videos are appropriate for anti-smoking campaigns.

\section{Participants}

Ninety undergraduate and graduate students from universities in Bangkok participated in this study. Participants were required to be a smoker with a smart phone or tablet using the IOS or Android operating system, and installed with the Line instant messaging application. Data was collected at universities and entertainment areas.

\section{Experimental procedures}

The experiment ran for about fifty minutes and consisted of four sections. Each participant was required to undertake the following steps: First, participants answered section one of the survey before being exposed to the anti-smoking multimedia campaign for each human-caring level. The questions in this section are a pre-test of three factors affecting intention to reduce smoking: attitude towards smoking, belief in subjective norms of smoking, and perceived behavioral control of smoking. Second, participants were presented with anti-smoking multimedia campaign grouped by human-caring level via Line instant messaging application. Third, participants answered section one of the survey after exposure to antismoking multimedia campaigns. The items in this survey section are post-test and similar with those in the first step. Apart from these three factors, participants also responded to three other items: intention to 
reduce smoking, motivation for smoking cessation, and smoking cessation behavior. Finally, participants filled in section two of the survey.

\section{RESULTS}

The research was directly conducted with 90 samples who were exposed to three different antismoking multimedia campaigns. Therefore, from the experimental procedures, 270 cases were used to analyze the difference between before and after viewing the different multimedia, and to analyze the difference between the groups. Ninety samples were included in the analysis of fit of the smokingcessation behavior model and participants' characteristics: demographic data, behavior in smoking cigarettes, and ranking of communication channels and types of anti-smoking multimedia campaigns. A detailed description of preliminary data screening indicated no missing or outlier data. In addition, the data met statistical assumptions such as normality and homoscedasticity.

Prior to testing the hypotheses, the measurement model of all constructs was assessed for model fit by using a congeneric measurement model. This congeneric measurement model assumes that each measurement model is related to only one latent variable (Anderson and Gerbing, 1988). The chi-square $\left(\mathrm{X}^{2}\right)$, relative chi-square (chi-square/degrees of freedom), root mean square error of approximation (RMSEA), goodness-of-fit index (GFI), adjusted goodness-of-fit index (AGFI), root mean square (RMS), and comparative fit index (CFI) were used to assess the fit of the model.

In general, model fit is considered to be adequate if chi-square is low relative to the degrees of freedom with an insignificant $p$ value ( $>0.05$ ). The relative chi-square should be 3 or less (Kline, 2011; Tabachnick and Fidell, 2013). The value of RMSEA should be less than 0.07 (Steiger, 2007) and goodness-of-fit index (GFI) and comparative fit index (CFI) should be greater than 0.90 (Segars and Grover, 1993). The value of AGFI should be larger than 0.8 (Bagozzi and Yi, 1988; Hair et al., 1998; JÖreskog and SÖrbom, 1994). The value of Cronbach's alpha is used to assess the reliability of a measurement model. The threshold for this value is Cronbach's alpha $>0.50$ (Hair et al., 1998). The resulting 22 items of six factor models have a suitable model fit. Table 4 presents the values of these items.

TABLE 4

FIT INDEX AND VALUES OF ITEMS OF EACH CONSTRUCT

\begin{tabular}{|l|c|c|c|c|c|c|}
\hline \multirow{2}{*}{ Fit index } & \multicolumn{6}{|c|}{ Values of the items of each construct } \\
\cline { 2 - 7 } & $\begin{array}{c}\text { Attitude } \\
\text { towards } \\
\text { smoking }\end{array}$ & $\begin{array}{c}\text { Belief in } \\
\text { subjective } \\
\text { norms of } \\
\text { smoking }\end{array}$ & $\begin{array}{c}\text { Perceived } \\
\text { behavioral } \\
\text { control of } \\
\text { smoking }\end{array}$ & $\begin{array}{c}\text { Intention } \\
\text { to reduce } \\
\text { smoking }\end{array}$ & $\begin{array}{c}\text { Motivation } \\
\text { for smoking } \\
\text { cessation }\end{array}$ & $\begin{array}{c}\text { Smoking } \\
\text { cessation } \\
\text { behavior }\end{array}$ \\
\hline $\begin{array}{l}\mathrm{X}^{2} \\
\text { insignificant }\end{array}$ & 0.132 & 0.053 & 0.639 & 0.569 & 0.131 & 0.926 \\
\hline $\mathrm{X}^{2} / \mathrm{df}<3$ & 2.266 & 2.738 & 0.219 & 0.325 & 2.034 & 0.009 \\
\hline GFI $>0.90$ & 0.996 & 0.991 & 1.000 & 0.999 & 0.992 & 1.000 \\
\hline AGFI $>0.80$ & 0.958 & 0.945 & 0.996 & 0.995 & 0.962 & 1.000 \\
\hline CFI >0.90 & 0.999 & 0.997 & 1.000 & 1.000 & 0.997 & 1.000 \\
\hline $\begin{array}{l}\text { RMSEA }< \\
0.07\end{array}$ & 0.069 & 0.068 & 0.000 & 0.028 & 0.062 & 0.000 \\
\hline $\begin{array}{l}\text { Cronbach } \\
\text { alpha }\end{array}$ & 0.938 & 0.959 & 0.907 & 0.913 & 0.901 & 0.907 \\
\hline
\end{tabular}

In this study, the participants are predominantly male ( $82 \%$ of the sample), aged between $20-22$ years $(58 \%)$, and are fourth-year university students (36\%). A paired-samples t-test was used to analyze the 
difference between before and after viewing different anti-smoking multimedia (text, text with pictures, and video) on attitude towards smoking, perceived behavioral control of smoking and belief in subjective norms of smoking, on the data of 270 cases of 90 participants. This statistic was used to test H1a - H1c. A p-value of .05 was used as the significance level in the statistical tests. A p-value between .05 and .10 is deemed as marginally significant. The second analysis using a structural equation model (SEM) was applied to test the fit of the smoking-cessation behavior model. This analysis incorporates attitude towards smoking, perceived behavioral control of smoking, belief in subjective norms of smoking, intention to reduce smoking, motivation for smoking cessation and smoking cessation behavior. The criteria to test the model fit were the same as criteria used to test the reliability and validity of the measurement model. This statistic was used to test H2-H6.

The results of a paired-samples t-test presented in Table 5 indicate some support of the effect of antismoking multimedia on attitude towards smoking, perceived behavioral control of smoking and belief of subjective norms. The statistical values support $\mathrm{H} 1 \mathrm{a}$ and $\mathrm{H} 1 \mathrm{~b}$. Participants will have less positive attitude toward smoking after being exposed to an anti-smoking multimedia campaign in the form of text, text with pictures, and video. This result agrees with several researchers (e.g., Sargent, 2005; Larsen and Cohen, 2009; and Kees et al., 2010) that multimedia in the form of text, text with pictures, and video will scare smokers after seeing the harm caused by cigarettes. Therefore, H1a is supported. Participants will perceive more behavioral control of smoking after being exposed to an anti-smoking multimedia campaign in the form of text, text with pictures, and video. This result is consistent with research results of Donovan and Carter (2003). Therefore, H1b is supported. However, the t-value does not show a significant difference between pre-test and post-test on belief in subjective norms of smoking. Thus, H1c is not supported. This result is in contrast to the result of McCool et al. (2014). The discrepancy may be due to the fact that most participants in this study are male (82\%), with ages between $20-22$ years, versus $37 \%$ male, $63 \%$ female, with ages of 16-17 years, in the McCool study. Male participants may be more easily influenced than females by friends and celebrity role models. Reducing the influence of belief in subjective norms of smoking requires a different type of campaign or longer, continuous campaigns - not a short campaign. 
TABLE 5

STATISTICAL TABLE OF T-TEST RESULTS

\begin{tabular}{|c|c|c|c|c|c|}
\hline \multirow[t]{2}{*}{ Variable } & \multicolumn{2}{|c|}{$\begin{array}{c}\text { Mean scores before } \\
\text { exposure to multimedia }\end{array}$} & \multicolumn{2}{|c|}{$\begin{array}{c}\text { Mean scores after } \\
\text { exposure to } \\
\text { multimedia }\end{array}$} & \multirow[t]{2}{*}{$\mathbf{t}$} \\
\hline & Mean & $\begin{array}{l}\text { Standard } \\
\text { deviation }\end{array}$ & Mean & $\begin{array}{l}\text { Standard } \\
\text { deviation }\end{array}$ & \\
\hline \multicolumn{6}{|c|}{ Anti-smoking campaign towards human care for environment with text } \\
\hline Attitude towards smoking & 2.850 & 0.814 & 2.442 & 0.885 & $\mathrm{t}=-2.488^{*}$ \\
\hline $\begin{array}{l}\text { Belief in subjective norms of } \\
\text { smoking }\end{array}$ & 2.700 & 1.169 & 2.589 & 0.715 & $\mathrm{t}=-0.598$ \\
\hline $\begin{array}{l}\text { Perceived behavioral control of } \\
\text { smoking }\end{array}$ & 3.783 & 0.835 & 4.042 & 1.026 & $\mathrm{t}=2.098^{*}$ \\
\hline \multicolumn{6}{|c|}{ Anti-smoking campaign towards human care for environment with text with pictures } \\
\hline Attitude towards smoking & 3.108 & 1.161 & 2.775 & 1.229 & $\mathrm{t}=-2.238^{*}$ \\
\hline $\begin{array}{l}\text { Belief in subjective norms of } \\
\text { smoking }\end{array}$ & 2.811 & 1.092 & 2.800 & 1.078 & $\mathrm{t}=-0.104$ \\
\hline $\begin{array}{l}\text { Perceived behavioral control of } \\
\text { smoking }\end{array}$ & 3.592 & 1.037 & 3.983 & 1.028 & $\mathrm{t}=4.032 *$ \\
\hline \multicolumn{6}{|c|}{ Anti-smoking campaign towards human care for environment with video } \\
\hline Attitude towards smoking & 3.225 & 0.829 & 2.508 & 0.775 & $\mathrm{t}=-4.510^{*}$ \\
\hline $\begin{array}{l}\text { Belief in subjective norms of } \\
\text { smoking }\end{array}$ & 3.067 & 1.185 & 3.000 & 1.292 & $\mathrm{t}=-0.332$ \\
\hline $\begin{array}{l}\text { Perceived behavioral control of } \\
\text { smoking }\end{array}$ & 3.783 & 0.727 & 4.225 & 0.729 & $\mathrm{t}=4.264^{*}$ \\
\hline \multicolumn{6}{|c|}{ Anti-smoking campaign towards human care for surrounding people with text } \\
\hline Attitude towards smoking & 2.608 & 0.751 & 2.125 & 0.703 & $\mathrm{t}=-3.511^{*}$ \\
\hline $\begin{array}{l}\text { Belief in subjective norms of } \\
\text { smoking }\end{array}$ & 2.778 & 1.070 & 2.711 & 0.865 & $\mathrm{t}=-0.477$ \\
\hline $\begin{array}{l}\text { Perceived behavioral control of } \\
\text { smoking }\end{array}$ & 3.517 & 0.653 & 4.058 & 0.776 & $\mathrm{t}=4.141^{*}$ \\
\hline \multicolumn{6}{|c|}{ Anti-smoking campaign towards human care for surrounding people with text with pictures } \\
\hline Attitude towards smoking & 2.967 & 0.937 & 2.575 & 1.055 & $\mathrm{t}=-2.926^{*}$ \\
\hline $\begin{array}{l}\text { Belief in subjective norms of } \\
\text { smoking }\end{array}$ & 2.911 & 1.283 & 2.811 & 0.908 & $\mathrm{t}=-0.532$ \\
\hline $\begin{array}{l}\text { Perceived behavioral control of } \\
\text { smoking }\end{array}$ & 3.525 & 0.854 & 3.783 & 0.853 & $\mathrm{t}=2.060^{*}$ \\
\hline \multicolumn{6}{|c|}{ Anti-smoking campaign towards human care for surrounding people with video } \\
\hline Attitude towards smoking & 2.683 & 0.774 & 2.175 & 0.692 & $\mathrm{t}=-3.727^{*}$ \\
\hline $\begin{array}{l}\text { Belief in subjective norms of } \\
\text { smoking }\end{array}$ & 3.222 & 1.257 & 3.167 & 1.286 & $\mathrm{t}=-1.153$ \\
\hline $\begin{array}{l}\text { Perceived behavioral control of } \\
\text { smoking }\end{array}$ & 3.575 & 0.634 & 3.825 & 0.737 & $\mathrm{t}=3.383^{*}$ \\
\hline
\end{tabular}


TABLE 5

STATISTICAL TABLE OF T-TEST RESULTS (CONTINUED)

\begin{tabular}{|c|c|c|c|c|c|}
\hline \multirow[b]{2}{*}{ Variable } & \multicolumn{2}{|c|}{$\begin{array}{l}\text { Mean scores before } \\
\text { exposure to multimedia }\end{array}$} & \multicolumn{2}{|c|}{$\begin{array}{c}\text { Mean scores after } \\
\text { exposure to multimedia }\end{array}$} & \multirow[b]{2}{*}{$\mathrm{t}$} \\
\hline & Mean & $\begin{array}{l}\text { Standard } \\
\text { deviation }\end{array}$ & Mean & $\begin{array}{l}\text { Standard } \\
\text { deviation }\end{array}$ & \\
\hline \multicolumn{6}{|c|}{ Anti-smoking campaign towards human care for themselves with text } \\
\hline Attitude towards smoking & 2.850 & 0.745 & 2.592 & 0.880 & $\mathrm{t}=-2.041^{*}$ \\
\hline $\begin{array}{l}\text { Believed in subjective norms of } \\
\text { smoking }\end{array}$ & 2.767 & 1.290 & 2.656 & 0.937 & $\mathrm{t}=-0.895$ \\
\hline $\begin{array}{l}\text { Perceived behavioral control of } \\
\text { smoking }\end{array}$ & 3.908 & 0.761 & 4.14 & 0.973 & $\mathrm{t}=1.628^{*}$ \\
\hline \multicolumn{6}{|c|}{ Anti-smoking campaign towards human care for themselves with text with pictures } \\
\hline Attitude towards smoking & 3.125 & 0.186 & 2.567 & 1.145 & $\mathrm{t}=-4.172^{*}$ \\
\hline $\begin{array}{l}\text { Belief in subjective norms of } \\
\text { smoking }\end{array}$ & 3.033 & 1.323 & 2.978 & 1.403 & $\mathrm{t}=-0.518$ \\
\hline $\begin{array}{l}\text { Perceived behavioral control of } \\
\text { smoking }\end{array}$ & 3.592 & 0.927 & 3.942 & 0.801 & $\mathrm{t}=2.740^{*}$ \\
\hline \multicolumn{6}{|c|}{ Anti-smoking campaign towards human care for themselves with video } \\
\hline Attitude towards smoking & 2.967 & 0.745 & 2.542 & 0.749 & $\mathrm{t}=-4.037^{*}$ \\
\hline $\begin{array}{l}\text { Belief of subjective norms of } \\
\text { smoking }\end{array}$ & 2.933 & 1.172 & 2.833 & 1.215 & $\mathrm{t}=-1.055$ \\
\hline $\begin{array}{l}\text { Perceived behavioral control of } \\
\text { smoking }\end{array}$ & 3.633 & 0.579 & 4.092 & 0.887 & $\mathrm{t}=4.600^{*}$ \\
\hline
\end{tabular}

$* \mathrm{p}<0.05$

The results of the direct, indirect, and total effects of the adjusted model with the standardized score, and goodness-of-fit indices of the proposed model are exhibited in Table 6. The results provide good support for three hypotheses, while not supporting two hypotheses. Attitude towards smoking and belief in subjective norms of smoking do not influence intention to reduce smoking. Hence, $\mathrm{H} 2$ and $\mathrm{H} 4$ are not supported. These results are in contrast with results from several researchers (e.g., Andrews et al., 2008; Khurshid and Ansari, 2012) which state that social norms (such as father, mother, and relative) and role models have a significant impact on intention to reduce smoking. The reasons for the contrasting research results could be that participants in this study are ages between 20-22 years with different individual beliefs; they tend to follow their beliefs as they think that they are correct while also look for reasons to support their beliefs. Whereas the participants in the Andrews et al. study had ages between 9-16 years individual beliefs may not be as strong in a younger population. Therefore, $\mathrm{H} 2$ and $\mathrm{H} 3$ are not supported. In addition, perceived behavioral control directly influences the intention to reduce smoking and indirectly influences smoking cessation behavior through intention to reduce smoking. These results are consistent with research from Smith et al. (2007) and Zheng et al. (2014) which indicate that information of negative effects of cigarettes will positively affect intention to control smoking. However, perceived behavioral control has a small impact on intention to reduce smoking $\left(\mathrm{R}^{2}=0.017\right)$, so H4 is supported. Finally, intention to reduce smoking and motivation for smoking cessation have a positive impact on smoking cessation behavior $\left(\mathrm{R}^{2}=0.290\right)$, so $\mathrm{H} 5$ and $\mathrm{H} 6$ are supported. These results are consistent with Carter et al. (2007) and White et al. (2008). 
TABLE 6

EFFECTS OF ADJUSTED MODEL WITH THE STANDARDIZED SCORE

\begin{tabular}{|c|c|c|c|c|c|c|c|}
\hline \multirow[b]{2}{*}{$\begin{array}{c}\text { Dependent } \\
\text { variables }\end{array}$} & \multirow[b]{2}{*}{$\mathbf{R}^{2}$} & \multirow[b]{2}{*}{ Relation } & \multicolumn{5}{|c|}{ Independent variables } \\
\hline & & & $\begin{array}{l}\text { Attitude } \\
\text { towards } \\
\text { smoking }\end{array}$ & $\begin{array}{c}\text { Belief in } \\
\text { subjective } \\
\text { norms of } \\
\text { smoking }\end{array}$ & $\begin{array}{c}\text { Perceived } \\
\text { behavioral } \\
\text { control of } \\
\text { smoking }\end{array}$ & $\begin{array}{c}\text { Intention } \\
\text { to reduce } \\
\text { smoking }\end{array}$ & $\begin{array}{l}\text { Motivation } \\
\text { for smoking } \\
\text { cessation }\end{array}$ \\
\hline \multirow{3}{*}{$\begin{array}{l}\text { Smoking } \\
\text { cessation } \\
\text { behavior }\end{array}$} & \multirow{3}{*}{0.290} & Direct & - & - & - & $0.318^{*}$ & $0.317^{*}$ \\
\hline & & Indirect & -0.013 & -0.010 & 0.038 & - & - \\
\hline & & Total & -0.013 & -0.010 & 0.038 & $0.318^{*}$ & $0.317^{*}$ \\
\hline \multirow{3}{*}{$\begin{array}{l}\text { Intention to } \\
\text { reduce } \\
\text { smoking }\end{array}$} & \multirow{3}{*}{0.017} & Direct & -0.042 & -0.032 & $0.121^{*}$ & - & - \\
\hline & & Indirect & - & - & - & - & - \\
\hline & & Total & -0.042 & -0.032 & $0.121^{*}$ & - & - \\
\hline \multicolumn{8}{|c|}{$\chi 2 / \mathrm{df}=1.155, \mathrm{p}$-value $=0.076, \mathrm{GFI}=0.938, \mathrm{AGFI}=0.912, \mathrm{CFI}=0.994, \mathrm{RMSEA}=0.024$} \\
\hline
\end{tabular}

\section{CONCLUSION}

In summary, the results of this study suggest that participants have less favorable attitudes toward smoking and more perceived behavioral control of smoking after they are exposed to anti-smoking multimedia campaigns (text, text with pictures, and video), grouped by human-caring level (environment, surrounding people, and themselves). However, all anti-smoking multimedia campaigns do not affect belief in subjective norms of smoking. In addition, perceived behavioral control directly influences intention to reduce smoking and indirectly influences smoking cessation behavior through intention to reduce smoking. Moreover, motivation for smoking cessation directly influences smoking cessation behavior. The research results, however, do not indicate the effect of attitude towards smoking and belief in subjective norms of smoking on intention to reduce smoking. Though $96 \%$ of participants believe that smoking is not good for one's health, they still continue to smoke cigarettes. The participants believe that smoking is challenging, interesting, joyful, worth trying, and helps relieve stress. In addition, they think that smoking makes them look good and more mature. Some smoke during social activities because they believe that non-smokers will not be accepted in a group they are attempting to join.

Government agencies should make anti-smoking campaigns among youths using multimedia as follows: First, to impact the attitude towards smoking and to enhance perception of behavioral control of smoking, the campaign should show the effects of cigarettes towards environment, surrounding people and smokers themselves with multimedia in the forms of text, text with pictures, and videos. In addition, government agencies should include in the campaigns elements to enhance motivation to reduce smoking. The preferred channel to use for the campaigns is the Line instant messaging application.

This research has several limitations that hamper the ability to generalize the study results. First, most of the participants in this research are male. The opinions and specific character of males may be different from those of females, so study findings may not be applicable to females. Also, the time provided for participants to view the anti-smoking multimedia campaigns was short, around fifty minutes. Effectively having an impact on a person's behavior may require more time to view the multimedia.

The results of this research provide sufficient grounds for conducting future research. As the results of this study do not show an effect of anti-smoking multimedia campaigns on belief in subjective norms of smoking, additional research should be made on how to reduce the impact of social norms. In addition, future research also needs to consider factors affecting attitude towards smoking in more detail. A new, engaging anti-smoking campaign, such as demonstrating how cigarette smoking can result in lung cancer and strokes, should be considered to gain attention from youths. 


\section{REFERENCES}

Al-Swidi, A., Huque, S. M. R., Hafeez, M. H., \& Shariff, M. N. M. (2014). The role of subjective norms in theory of planned behavior in the context of organic food consumption. British Food Journal, $116(10), 1561-1580$.

Anderson, J. C., and Gerbing, D. W. (1988). Structural Equation Modeling in Practice: A Review and Recommended Two-Step Approach. Psychological Bulletin, 103(3), 411-423.

Andrews, J. A., Hampson, S., \& Barckley, M. (2008). The Effect of Subjective Normative Social Images of Smokers on Children's Intentions to Smoke. Nicotine Tob Res, 589-597.

Ajzen, I. (1991). The Theory of Planned Behavior. USA: Academic Press. Inc.

Ajzen, I., \& Fishbein, M. (2005). The influence of attitudes on behavior. New York and London: Psychology Press.

Bagozzi, R.P. \& Yi, Y., (1988). On the evaluation of structural equation models. Journal of the Academy of Marketing Science, 16(1), 74-94.

Bicchieri, C., \& Muldoon, R. (2011). Social Norms. Stanford Encyclopedia of Philosophy.

Bizer, G. Y., Barden, J. C., \& Petty, R. E. (2003). Attitudes. Encvclopedia of comitive science, 1, $247-$ 253.

Cameron, R., Ginsburg, H., Michael Westhoff, M., \& Mendez, R. V. (2012). Ajzen's Theory of Planned Behavior and Social Media Use by College Students. American journal of psychological research, $8(1)$.

Donovan, R., \& Carter, O. (2003). Evidence for Behaviour Change from Media Based Public Education Campaigns: Implications for a Campaign to Reduce Time-to-care for Patients with Acute Myocardial Infarction. Centre for Behavioural Research in Cancer Control Curtin University of Technology.

Egmond, C., \& Bruel, R. (2007). Nothing is as practical as a good theory, Analysis of theories and a tool for developing interventions to influence energy-related behavior. Unpublished doctoral dissertation, SenterNovem.

Gerber, A.S., \& Rogers, T. (2009). Descriptive Social Norms and Motivation to Vote: Everybody's Voting and so Should You. The Journal of Politics, 71(1), 178-191.

Hair, J. F., Anderson, R.E., Tatham, R.L., \& Black, W.C. (1998). Multivariate Data Analysis, 5th ed. Englewood Cliffs, NJ: Prentice-Hall.

Harsono, L. D., \& Suryana, L. A. (2014). Factors Affecting the Use Behavior of Social Media Using UTAUT 2 Model. Paper presented at the First Asia-Pacific Conference on Global Business, Economics, Finance and Social Sciences, Singapore.

Jain, V. (2014). 3D model of attitude. International Journal of Advanced Research in Management and Social Sciences, 3(3).

JÖreskog, K., \& SÖrbom, D. (1994). Structural Equation Modeling with the SIMPLIS Command Language. Chicago, IL: Scientific Software International.

Kees, J., Burton, S., Andrews, J. C., \& Kozup, J. (2010). Understanding How Graphic Pictorial Warnings Work on Cigarette Packaging. Journal of Public Policy \& Marketing, 29 (2), 265-276.

Khurshid, D. F., \& Ansari, U. (2012). Causes of smoking habit among the teenagers. Institute of Interdisciplinary Business Research, 3(9).

Kline, R. B. (1998). Principles and practice of structural equation modeling. New York: Guilford Press.

Kotler, P., \& Keller, K. L. (2012). Marketing Management. Boston: Pearson Prentice Hall.

Kraft, P., Rise, J., Sutton, S., \& Roysamb, E. (2005). Perceived difficulty in the theory of planned behaviour: Perceived behavioural control or affective attitude?. British Journal of Social Psychology, 44, 479-496.

Larsen, J. T., \& Cohen, L. M. (2009). Smoking attitudes, intentions, and behavior among college student smokers: Positivity outweighs negativity. Informa UK Ltd., USA.

Levitt, M. (2013). Perceptions of nature, nurture and behavior. Unpublished doctoral dissertation, Life Sciences, Society and Policy. 
Mahagunta, S., \& Anglin, G.J. (2007). The effects of concurrent of presentation of animation with verbal and textual narration, and animation presentation before and after text narration on retention, matching and transfer test scores. Unpublished doctoral dissertation, University of Kentucky.

Maoyan., Zhujunxuan., \& Sangyang. (2014). Consumer Purchase Intention Research Based on Social Media Marketing. International Journal of Business and Social Science, 5, 10(1), 92-97.

Mayer, E. R. (2005). The Cambridge Handbook of Multimedia Learning. UK: Cambridge University Press.

McCool, J., Freeman, B., \& Tanielu, H. (2014). Perceived social and media influences on tobacco use among Samoan youth. BMC Public Health, 14, Article number 1100. doi: 10.1186/1471-245814-1100.

Mcgloughlin, 2001. Multimedia Concept and Practice. Prentice Hall inc.

Mo, S. (2011). An Exploratory Study of Intrinsic \& Extrinsic Motivators And Student Performance In An Auditing Course. American Journal of Business Education, 4(2), February, 19-25.

Mohan, A. (2014). Consumer behavior towards smartphone industry in indian market. Unpublished doctoral dissertation, Dublin Business School.

Morvan, K. G., Gabriel, P., Ely, M. L. E., Rieunier, S., \& Urien, B. (2009). The use of visual warnings in social marketing: The case of tobacco. Journal of Business Research.

National Statistical Office. Ministry of Digital Economy and Society. (2014). Survey on smoking and drinking behavior of Thai population in 2014. Bangkok: National Statistical Office.

Pande, A. C., \& Soodan, V. (2015). Role of consumer attitudes, beliefs and subjective norms as predictors of purchase behavior : a study on personal care purchases. The Business \& Management Review, 5(4). 285-291.

Plass, J. L., Homer, B. D., \& Hayward, E. O. (2009). Design factors for educationally effective animations and simulations. Springer, 21, 31-61.

Sargent., J. D. (2005). Smoking in Movies: Impact on Adolescent Smoking. Elsevier, 345-370.

Segars, A. H., \& Grover, V. (1993). Re-examining perceived ease of use and usefulness: A confirmatory factor analysis. MIS Quarterly, 17(4), 517-525.

Schiffiman, L.G., Kanuk, L.L., \& Wisenblit, J. (2006). Consumer Behavior. Boston: Pearson Prentice Hall.

Smith, B. N., Bean, M. K., Mitchell, K. S., Speizer, L S., \& Fries, E. A. (2007). Psychosocial factors associated with non-smoking adolescents' intentions to smoke. Health education research, 22(2), 238-247.

Smith, W. R., \& Vardiabasis, D. (2010). Using social media as a competitive advantage: the case of small businesses. Problems and Perspectives in Management, 8(4).

Steiger, J. H. (2007). Understanding the limitations of global fit assessment in structural equation modeling. Personality and Individual Differences, 42(2007) 893-898.

Tabachnick, B. G. and Fidell, L. S. (2007). Using Multivariate Statistics (Fifth Edition). New York: Pearson.

Thai Health Promotion Foundation. (2014). Annual report 2014. Bangkok: Thai Health Promotion Foundation.

Watson, J. (2008). Nursing: The Philosophy and Science of Caring (rev.ed.). Boulder: University Press of Colorado.

Zheng, P., Kegler, M.C., Berg, C.J., Fu, W., Wang, J., Zhou, X., Liu, D., \& Fu, H. (2014). Correlates of Smoke-Fee Home Policies in Shanghai, China. Biomed Res Int., Jul, 20-43.

Zikmund, W.G., Babin, B. J., Carr, J.C., \& Griffin, M. (2010). Busines research method. Canada: Cengage learning. 